\title{
A novel blood-based biomarker for detection of autism spectrum disorders
}

\author{
N Momeni ${ }^{1}$, J Bergquist ${ }^{2}$, L Brudin ${ }^{3}$, F Behnia $^{4}$, B Sivberg ${ }^{5}$, MT Joghataei ${ }^{6}$ and BL Persson ${ }^{1}$
}

Autism spectrum disorders (ASD) are classified as neurological developmental disorders. Several studies have been carried out to find a candidate biomarker linked to the development of these disorders, but up to date no reliable biomarker is available. Mass spectrometry techniques have been used for protein profiling of blood plasma of children with such disorders in order to identify proteins/peptides that may be used as biomarkers for detection of the disorders. Three differentially expressed peptides with mass-charge $(\mathrm{m} / \mathrm{z})$ values of $2020 \pm 1,1864 \pm 1$ and $1978 \pm 1 \mathrm{Da}$ in the heparin plasma of children with ASD that were significantly changed as compared with the peptide pattern of the non-ASD control group are reported here. This novel set of biomarkers allows for a reliable blood-based diagnostic tool that may be used in diagnosis and potentially, in prognosis of ASD. Translational Psychiatry (2012) 2, e91; doi:10.1038/tp.2012.19; Published online 13 March 2012

\section{Introduction}

Autism spectrum disorders (ASD) are characterized by impairments in social orientation, communication and repetitive or restricted patterns of interests or behaviors appearing during the first 3 years of life with onset from birth or gradually in a regressive process from the end of the first year but mainly during the second year ${ }^{1,2}$ and is in Diagnostic and Statistical Manual of Mental Disorders (DSM)-IV classified as a developmental disorder. ${ }^{3}$ The pathogenesis of ASD is not yet known. Diagnosis is based on DSM-IV criteria and consists of a triad of symptoms, including social impairment, language disturbances and a rigid adherence to sameness.

In children diagnosed with ASD there is a spectrum of severity of these symptoms reflecting a variation in cognitive development ranging from above average to intellectual disability. ${ }^{4,5}$ Boys are $4-5$ times more likely than girls to have autism. ${ }^{6}$ Although the genetic determinants of ASD are so far largely unknown a recent report describes enrichments in different gene sets known to be linked to ASD. ${ }^{7}$ Pathophysiology of ASD involves affected cellular and neuronal development and function possibly associated with abnormal patterns of proteins/peptides in the blood and the cerebrospinal fluid, ${ }^{8-10}$ increased levels of neurotransmitter serotonin and $\beta$-endorphin, ${ }^{11-13}$ low levels of melatonin, ${ }^{14}$ increased levels of opioid, ${ }^{15}$ high levels of homocysteine, ${ }^{16} \mathrm{Ca}^{2+}$ channel deficiency, ${ }^{17}$ gene-environment interactions, ${ }^{18}$ altered levels of serine protease prolyl endopeptidase activity, ${ }^{19}$ low plasma levels of the neuropeptide hormone oxytocin, ${ }^{20}$ elevated immune response $\mathrm{e}^{21}$ and abnormal activation of the complement system. ${ }^{22-24}$ Complement-system activation in response to a foreign antigen or a genetic disorder leads to degradation of complement protein $\mathrm{C}$ to $\mathrm{C} 3 \mathrm{a}$ and $\mathrm{C} 3 \mathrm{~b}$ protein fragments with molecular masses of about $9 \mathrm{kDa}$ and $177 \mathrm{kDa}$, respectively. ${ }^{25}$ Complement factor I-mediated cleavage of the C3b $\alpha$-chain liberates three protein fragments with molecular masses of 68,43 and $2 \mathrm{kDa},{ }^{26}$ of which the last one is known as C3f. ${ }^{27,28}$ The C3f peptide has been shown to have weak spasmogenic and anaphylatoxic functions and enhances vascular permeability as shown in guinea pig skin tests. ${ }^{28}$ Further degradation of C3f to C3f-desArg mediated by carboxypeptidase $\mathrm{N}$ was shown to result in stronger spasmogenic and anaphylatoxic properties. ${ }^{28}$ Figure 1 illustrates the location of the C3f domain in the crystal structure of the C3 protein. ${ }^{29}$ Detection of low-molecular-weight peptides by proteomic profiling of blood plasma and cerebrospinal fluid may reveal altered protein/peptide patterns associated with diseases and disorders. ${ }^{30-33}$ In a recent study, adults with Asperger's syndrome was shown to exhibit sex-specific expression of serum biomarkers. ${ }^{33}$ Previous attempts to find a reliable biomarker for ASD by use of proteomics and protein/peptide profiling have led to a set of potential biomarkers. A proteomic study on autopsied autism brains using 2-D gel electrophoresis revealed a single-nucleotide polymorphism in glyoxalase I. ${ }^{34}$ Another proteomic study of serum from children with autism showed differential expression of apolipoproteins and other components of complement proteins. ${ }^{35}$

In this study, we undertook a proteomic approach using surface-enhanced laser desorption/ionization time-of-flight (SELDI TOF) mass spectrometry to compare peptide profiles of blood plasma from children with ASD and control children (Table 1) with the aim of discovering novel peptide biomarkers with diagnostic utility and to understand the role of these in the pathophysiology of ASD.

\footnotetext{
${ }^{1}$ School of Natural Sciences, Linnaeus University, Kalmar, Sweden; ${ }^{2}$ Department of Chemistry-Biomedical Centre, Analytical Chemistry, Uppsala University, Uppsala, Sweden; ${ }^{3}$ Department of Clinical Physiology, Kalmar County Hospital, Kalmar, Sweden; ${ }^{4}$ Department of Occupational Therapy, University of Social Welfare and Rehabilitation Sciences, Tehran, Iran; ${ }^{5}$ Department of Health Sciences, Lund University, Lund, Sweden and ${ }^{6}$ Cellular and Molecular Research Centre, Tehran Medical University, Tehran, Iran

Correspondence: Professor BL Persson, School of Natural Sciences, Linnaeus University, Norra vagen 49, Kalmar SE-39182, Sweden.

E-mail: bengt.persson@ Inu.se
}

Keywords: ASD; autism spectrum disorders; biomarker; blood

Received 3 Feburary 2012; accepted 4 February 2012 


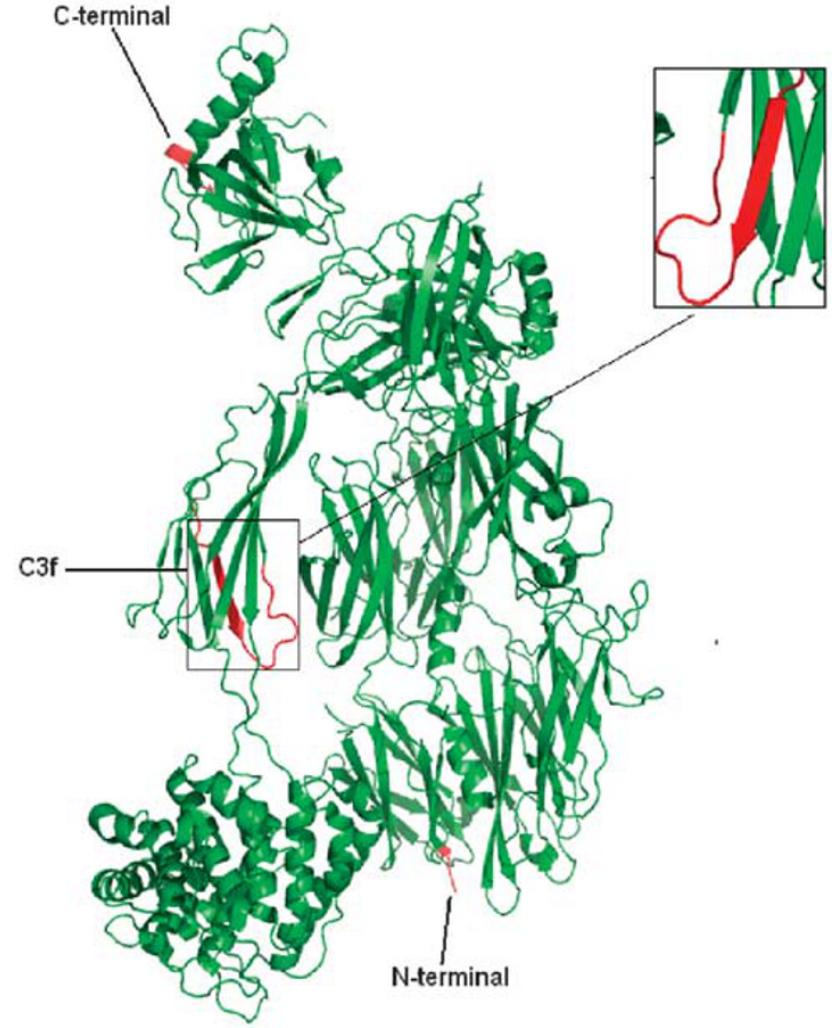

Figure 1 Crystal structure of complement protein $\mathrm{C} 3(\mathrm{C} 3 \mathrm{~b} / \mathrm{A} / 1)$ with location of C3f domain. Location of C3f domain (boxed) in structure model from PyMol (DeLano Scientific LLC, San Carlos, CA, USA).

Table 1 Participant details

\begin{tabular}{lccc}
\hline & $\begin{array}{c}\text { ASD } \\
(\mathbf{n}=\mathbf{2 8})\end{array}$ & $\begin{array}{c}\text { Controls } \\
(\mathbf{n}=\mathbf{3 0})\end{array}$ & $\begin{array}{c}\text { Difference } \\
\mathbf{P}^{\mathbf{a}}\end{array}$ \\
\hline $\begin{array}{l}\text { Gender } \\
\quad \text { Males }\end{array}$ & 23 & 14 & \\
$\quad$ Females & 5 & 16 & 0.007 \\
Age & & & \\
$\quad$ Mean (s.d.) & $5.0(1.7)$ & $6.1(2.3)$ & \\
$\quad$ Median (range) & $5(3-9)$ & $6(3-12)$ & 0.060 \\
$\quad$ & & & \\
$\begin{array}{l}\text { Medication } \\
\quad \text { Risperdal only or in combination } \\
\quad \text { Ritalin only or in combination } \\
\quad \text { No specific medication }\end{array}$ & 18 & 0 & - \\
& 4 & 0 & - \\
\hline
\end{tabular}

Abbreviation: ASD, autism spectrum disorders.

aFisher's exact test for categorical and Mann-Whitney's U-test for continuous parameters.

\section{Subjects and methods}

Participants. Thirty-two children with ASD and thirty-one healthy control children were initially selected for this study. Children in the ASD group were recruited from the autism rehabilitation centre at the University of Social Welfare and Rehabilitation Sciences in Tehran, Iran. After receiving the informed consent from the parents, blood samples were collected. All children with ASD were examined by clinical experts on autism. A child psychiatrist examined all the children who were also examined by a child neurologist or a child psychiatrist. All consultants agreed on the diagnosis of autism according to the DSM-IV criteria. ${ }^{3}$ However, diagnostic procedures applied in Europe and USA/Canada using the Autism Diagnostic Observation Schedule ${ }^{36}$ and the Autism Diagnostic Interview-Revised ${ }^{37}$ were not used in the diagnostic process applied in Iran. This shortcoming was met by long clinical experience by the child neurologist/child psychiatrist who was aware of the core behaviors in autism stated by the American Academy of Pediatrics in its Embargo from 2007. ${ }^{38}$ All children in the ASD group were diagnosed as having autistic syndrome (infantile or Kanner autism) with varying degree of mental retardation but no information about other psychiatric disorders like autoimmune disorders was available besides that none of the children were schizophrenic. The control group consisted of healthy and typically developed children with no signs or diagnoses of neurodevelopmental disorders and was recruited from the same area in order to minimize toxic influences from different environments. Children both in the ASD and control groups who had any kind of infection or disease less than 2 weeks before the time of examination were excluded.

Blood samples for one healthy control (female) and four patients (two females and two males) were not possible to analyze owing to the too small sample volume, resulting in 30 controls and 28 children for children with ASD for further studies (For participant details, see Table 1). The ASD group comprised more males and was insignificantly younger.

The study was approved (MT/1247) by the ethics committee of the University of Medical Sciences, Tehran.

Procedure. All blood samples were collected by a pediatric nurse and the children diagnosed with autism were supervised by a pediatric psychiatrist with special training in the field of childhood psychosis. Venous blood was collected into 3-ml Heparin tubes (Vacutainer System; Becton-Dickinson, Plymouth, UK) and plasma was separated immediately by centrifugation at $1300 \mathrm{~g}$ for $10 \mathrm{~min}$ at $4{ }^{\circ} \mathrm{C}$. Immediately thereafter, an EDTA-free inhibitor cocktail (Halt protease inhibitor; Thermo Scientific Pierce Protein Research Products, Rockford, IL, USA) and Prefablock SC (Pentapharm, Munich, Germany) were added at a concentration of $10 \mu \mathrm{ml}^{-1}$ plasma and $20 \mu \mathrm{lml}^{-1}$ plasma, respectively. The produced plasma was aliquoted in small portions and immediately frozen on dry ice and stored at $-80^{\circ} \mathrm{C}$.

Peptide profiling. SELDI-TOF mass spectrometry (MS) was used to profile low-molecular weight peptides, less than $10 \mathrm{kDa}$, in the plasma of children with ASD and the healthy control group, suitable for the subsequent MS/MS analysis (described below) by matrix-assisted laser desorption/ionization (MALDI)-TOF/TOF MS and post source decay fragmentation. Carboxy methyl CM10 protein chip array surfaces (a weakcation exchanger bearing the $\mathrm{COOH}$ functional group) with eight application spots were prepared according to the manufacturer's protocol (BioRad, Hercules, CA, USA). CM10 protein chip arrays were equilibrated twice with $100 \mu \mathrm{l}$ buffer (0.1 M sodium acetate, $\mathrm{pH} 5.0$ ) for $5 \mathrm{~min}$ at $25^{\circ} \mathrm{C}$. Plasma samples diluted 1:50 with sodium phosphate buffer $(25 \mathrm{~mm}$, $\mathrm{pH}$ 7.0) were applied onto the bioprocessor well. After $45 \mathrm{~min}$ 
of incubation with shaking at $25^{\circ} \mathrm{C}$ samples were washed three times with $150 \mu \mathrm{l}$ of dilution buffer, followed by two quick rinses with $150 \mu \mathrm{l}$ of $1 \mathrm{~mm}$ HEPES buffer, $\mathrm{pH}$ 7.0. The chip array was removed from the bioprocessor, air-dried and $0.8 \mu \mathrm{l}$ of saturated $(25 \mathrm{mg} / \mathrm{ml}) \mathrm{CHCA}(\alpha$-cyano-4-hydroxycinnamic acid; BioRad) was added to each spot, allowed to air-dry, and this step was repeated once. The chip array was read on BioRad protein chip reader (PCS 4000) on SELDI system personal edition. Before reading the chip arrays an external calibration was performed by use of 'all-in-one peptide standard' (BioRad) containing a mixture of seven different peptides in the molecular range of $1-7 \mathrm{kDa}$.

Sequencing of peptides. $100 \mu \mathrm{l}$ of plasma samples were diluted with $300 \mu$ l of $25 \mathrm{~mm}$ sodium phosphate buffer, $\mathrm{pH} 7.0$, and subjected to ultrafiltration by use of a $10-\mathrm{kDa}$ Microne membrane (Millipore, Bedford, MA, USA). Ultrafiltrate was dried in a Speed Vacuum centrifuge, reconstituted in $10 \mu \mathrm{l}$ of $20 \mathrm{~mm}$ sodium phosphate buffer, $\mathrm{pH} 7.0$, and desalted on ZipTip C-18 columns (Millipore). Five microliters of the sample was applied on the prepared SELDI chip, incubated, washed and dried (as described above). One microliter of saturated $\left(25 \mathrm{mg} \mathrm{ml}^{-1}\right) \mathrm{CHCA}$ was added to the spots, allowed to air-dry, and this step was repeated once.

The MALDI TOF/TOF MS instrument used for sequence verification of the peptides was an Ultraflex II TOF/TOF
(Bruker Daltonics $\mathrm{GmbH}$, Bremen, Germany) equipped with a SmartBeam laser. All spectra were acquired using the reflectron mode. To acquire MS/MS spectra, post source decay TOF/TOF by laser-induced dissociation was performed. The target of choice for the MALDI approach was a SELDI-TOF target (BioRad). The prepared matrix/sample spots were introduced into the Ultraflex II and MS spectra were recorded from each prepared sample spot. The calibration used was an external near-neighbor calibration. The samples used for calibration were a mixture of peptides covering the mass range of $1-5 \mathrm{kDa}$. From the acquired peptide masses (TOF MS), the candidate peptides were selected manually for subsequent experiments. Spectra were annotated with data processing software, FlexAnalysis (Bruker Daltonics $\mathrm{GmbH}$, Bremen, Germany), and finally interpreted by software assisted de novo sequence analysis (BioTools, Bruker Daltonics $\mathrm{GmbH}$ ). The results from MALDI TOF/TOF MS were confirmed by analysis using high-resolution nano-LCESI FTICR MS.

Data analysis and statistics. The peak intensity from the SELDI TOF mass spectra were analyzed in triplicate and mean values were calculated. These were log-normally distributed and the following analyses were, therefore, made using logarithmic values. Group differences of the individual peaks were analyzed using Student's $t$-test, and for combination of

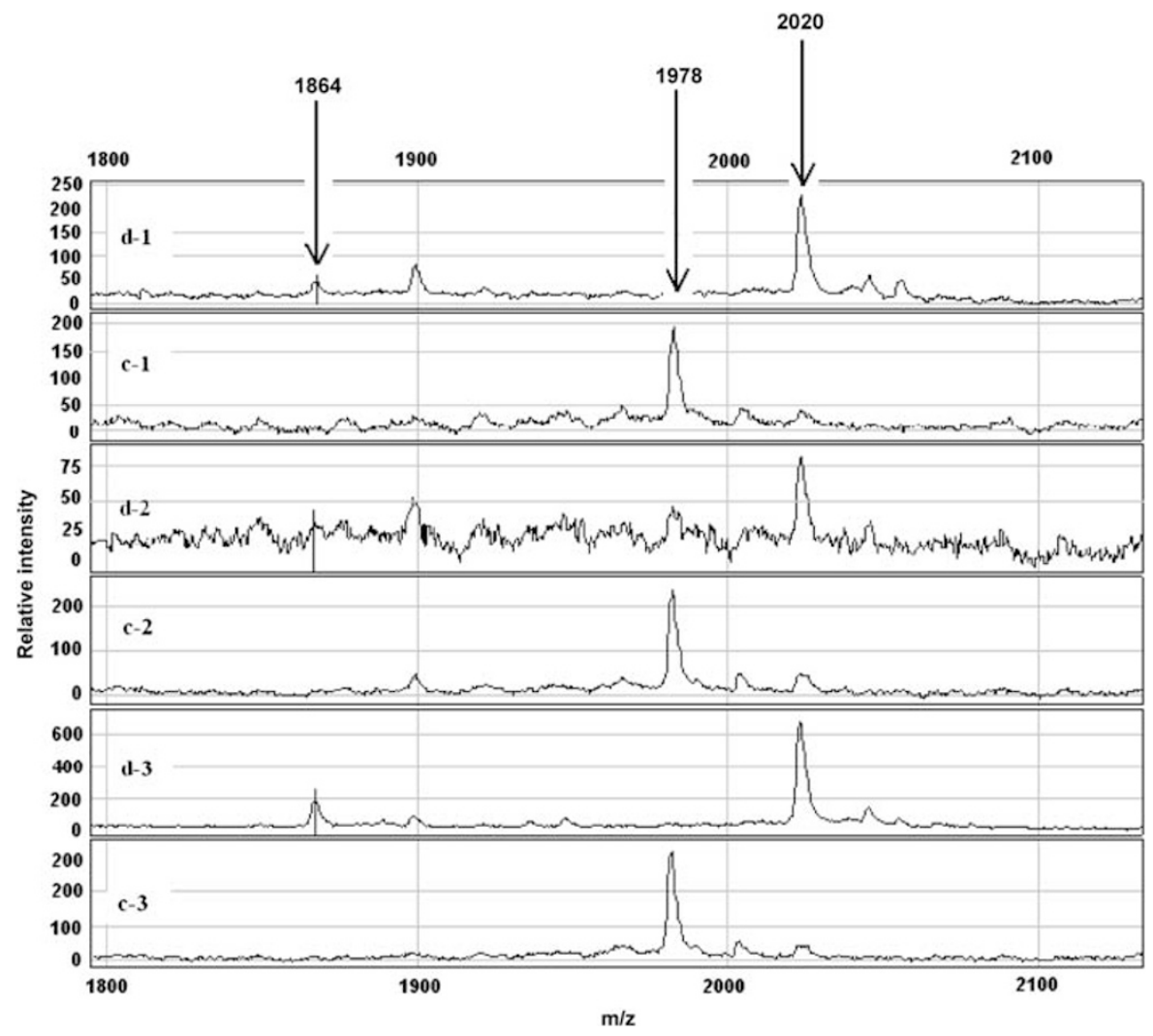

Figure 2 Typical SELDI TOF-derived mass spectra of plasma from children diagnosed with ASD and control children. Non-hemolytic samples were from three children diagnosed with ASD ( $d-1, d-2, d-3)$ and from three control children (c-1, c-2, c-3). The analysis was a blind test with the identities of the children unknown. Following analysis the identities of the children were revealed: $d-1$ (male, age 5), c-1 (female, age 5), d-2 (male, age 6), c-2 (male, age 7), d-3 (female, age 4) and c-3 (female, age 5). The positions of the three peptides, $1864 \pm 1,1978 \pm 1$, and $2020 \pm 1 \mathrm{Da}$, are indicated. 
the peaks, two-group discrimination analysis was used. ${ }^{39}$ Discrimination analysis gives a linear combination of three peaks (composite variable) that maximizes the distance between the mean values of the two groups (the so-called general distance) that is calculated as $\left(z_{A}-z_{B} / \sqrt{ }\right.$ variance of $z$ between groups, where $z_{A}$ and $z_{B}$ are the mean values for the two groups $A$ and $B$ for a specific set of parameters (ASD index). Because of uncertainties of the impact of hemolysis, ${ }^{40}$ the analysis was made using non-hemolytic samples only $(n=49)$, but the ASD index was calculated for all subjects (Table 3). Receiver operating characteristic curves ${ }^{41}$ were then constructed for all 58 subjects and for those 49 without hemolysis (Figure 3 ). Of all 58 participants comprising 30 control children and 28 children in the ASD group, 11 'outliers', 7 in the control group and 4 in the ASD group, were identified. Of the 49 participant samples without hemolysis (27 control children and 22 ASD group children) five 'outliers', four in the control group and one in the ASD group, were observed. Fisher's exact test was used to test differences between sex and age-categories, and age differences were also tested with Mann-Whitney's U-test (Table 1). For receiver operating characteristic analysis the statistical

Table 2 Peptides that expressed differentially in children with ASD in comparison with the control children

\begin{tabular}{lccr}
\hline $\begin{array}{l}\text { Average } \\
\text { mass }\end{array}$ & $\begin{array}{c}\text { Monoisotopic } \\
\text { mass }\end{array}$ & Sequence & P-value \\
\hline 2021.31 & 2020.10 & SSKITHRIWHESASLLR & $<0.001$ \\
1865.12 & 1864.00 & SSKITHRIWHESASLL & 0.003 \\
1979.27 & 1978.08 & SSKITHRIWHESASLLR* & 0.026 \\
\hline
\end{tabular}

Abbreviation: ASD, autism spectrum disorders.

$\mathrm{R}^{\star}$ : modified arginine residue at the C-terminal of C3f where arginine loses $\mathrm{NH}=\mathrm{C}-\mathrm{NH}_{2}$ moiety at the R-chain.

$P$-values calculated by log value and Student's $t$-test. program MedCalc (version 6.10, 2001; Frank Schoonjans, Mariakerke, Belgium) was used and all other statistical analyses were carried out using Statistica (version 8, Statsoft, Tulsa, OK, USA). A $P$-value of less than 0.05 was considered significant.

\section{Results}

The results show significant group differences of the intensity of the three different peaks with mass to charge ratios $(\mathrm{m} / \mathrm{z})$ 1864, 1978, and $2020 \pm 1 \mathrm{Da}$ (Figure 2; Table 2) both in univariate (individual peaks; not shown) and in the multivariate (composite peaks) analysis (Table 3; Figure 3). The peaks with an $\mathrm{m} / \mathrm{z}$ of 1864 and $2020 \pm 1 \mathrm{Da}$ were upregulated and overrepresented in children with ASD, whereas the peptide of $1978 \pm 1$ Da was downregulated in the children with ASD as compared with the healthy control children. The peptides were selected based on their discriminating abilities. In addition, the mass and intensity of the peptides is determining the possibility to subsequently identify and sequence them with MALDI-TOF/TOF MS and ESI-FTICR MS. From the acquired peptide masses (SELDI TOF MS data), the candidate peptides, for example, those with an $\mathrm{m} / \mathrm{z}$ of $2020 \pm 1$, were selected (Figure 4) and the amino-acid sequences were determined using tandem MS (MALDI TOF/TOF MS) as shown in Table 2. These sequences were also confirmed by nano-LC-ESI FTICR MS (not shown). The first peptide with an $\mathrm{m} / \mathrm{z}$ of $2020 \pm 1 \mathrm{Da}$ consists of 17 amino-acid residues corresponds to the peptide known as C3f (NCBI accession number 1413205A) of the complement protein C3 (Figure 1). The second peptide with an $\mathrm{m} / z$ of $1864 \pm 1$ Da corresponds to a peptide of 16 residues with the same sequence as C3f but lacks the C-terminal arginine and is known as C3fdesArg. The third peptide with an $\mathrm{m} / \mathrm{z}$ of $1978 \pm 1 \mathrm{Da}$ that appears at higher concentration in the group of healthy control children has the same sequence as C3f but carries a

Table 3 Results from ROC curve analysis showing individual peaks and the composite variable (combined) for all subjects (top) and those without sample hemolysis (bottom).

\begin{tabular}{|c|c|c|c|c|}
\hline & \multicolumn{3}{|c|}{ All subjects $(\mathrm{n}=58)$} & \multirow[t]{2}{*}{ Combined } \\
\hline & $2021 D a$ & $1865 D a$ & $1979 D a$ & \\
\hline $\begin{array}{l}\text { ROC area (AUC) } \\
95 \% \mathrm{Cl} \\
P \text {-value } \\
\text { Cutoff values }^{\mathrm{b}} \\
\text { Sens/spec } \\
\text { Cutoff values } \\
\text { Sens. at spec. } \geqslant 80 \%\end{array}$ & $\begin{array}{c}0.724 \\
0.591-0.833 \\
<0.001 \\
>5.40 \\
54 / 93 \\
>5.22 \\
64 / 80\end{array}$ & $\begin{array}{c}0.745 \\
0.614-0.850 \\
<0.001 \\
>3.10 \\
89 / 57 \\
>3.52 \\
57 / 80\end{array}$ & $\begin{array}{c}0.668 \\
0.532-0.786 \\
0.018 \\
\leqslant 4.53 \\
75 / 63 \\
\leqslant 3.88 \\
32 / 87\end{array}$ & $\begin{array}{c}0.814 \\
0.690-0.904 \\
<0.001 \\
>3.92 \\
86 / 77 \\
>4.33 \\
79 / 83\end{array}$ \\
\hline
\end{tabular}

ROC area (AUC)

$95 \% \mathrm{Cl}$

$P$-value ${ }^{a}$

Cutoff values $^{\text {b }}$

Sens/spec

Cutoff values $^{\text {b }}$

Sens. at spec. $\geqslant 80 \%$

Samples without hemolysis $(\mathrm{n}=49)$

\begin{tabular}{cccc}
\hline 0.818 & 0.754 & 0.749 & 0.923 \\
$0.682-0.914$ & $0.610-0.866$ & $0.605-0.862$ & $0.809-0.979$ \\
$<0.001$ & $<0.001$ & $<0.001$ & $<0.001$ \\
$>5.13$ & $>3.10$ & $\leqslant 4.50$ & $>4.21$ \\
$82 / 74$ & $91 / 52$ & $82 / 67$ & $95 / 85$ \\
$>5.22$ & $>3.54$ & $\leqslant 4.07$ & $>4.21$ \\
$73 / 81$ & $55 / 81$ & $50 / 81$ & $95 / 85$ \\
\hline
\end{tabular}

Abbreviations: ASD, autism spectrum disorders; AUC, area under the curve; Cl, confidence interval; ROC, receiver operating characteristic; sens., sensitivity; spec., specificity.

${ }^{a}$ AUC different from 0.5 .

bogarithm of peak energy. 
modified arginine residue, corresponding to ornithine, in the C-terminus

The results show a significant difference between the mean of the an $\mathrm{m} / \mathrm{z}$ values of these peptide intensities from children

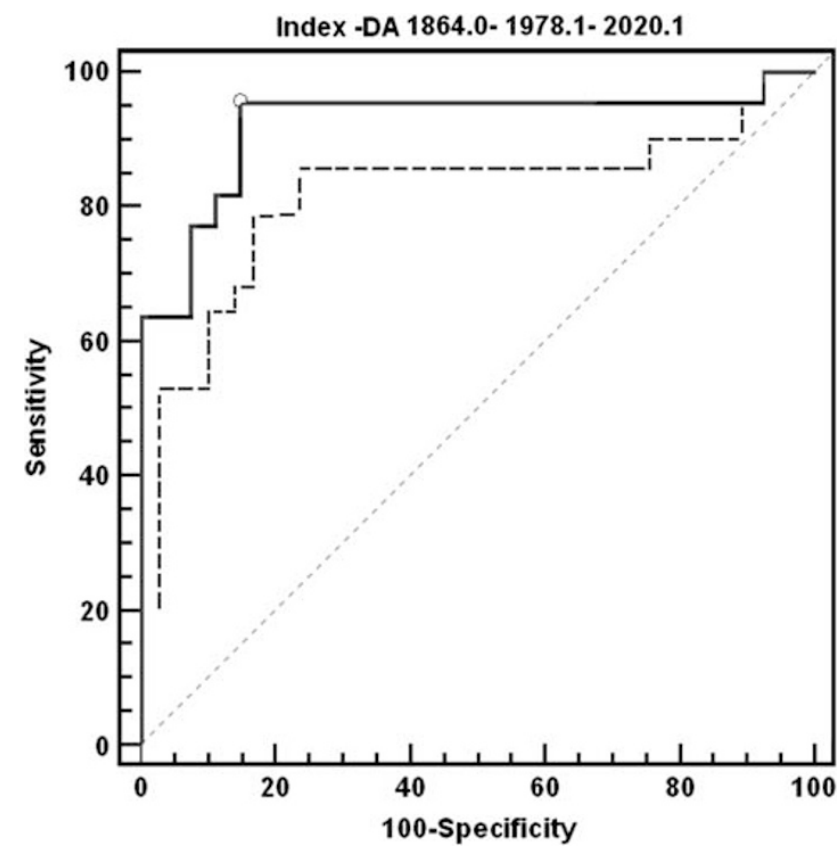

Figure 3 Receiver operating characteristic curves for all 58 subjects and for those 49 corrected for hemolysis. A composite of data for the peptides $1864 \pm 1$, $1978 \pm 1$ and $2020 \pm 1$ in the group of 58 participants (hatched line) and in the group of 49 non-hemolytic participants (solid line). For the group of non-hemolytic participants, sensitivity and specificity is 95.5 and 85.2 , respectively. Criterion value is $>4.2068$. Differences between curves, $0.923-0.814=0.109$, is not statistically significant $(P=0.141)$. with ASD and the control group with $P$-values $<0.05$ of the selected peptides (Table 2).

\section{Discussion}

Before starting this study, different aspects that might have an impact on the resulting spectra such as collection, handling and processing of samples, including choice of protease inhibitors, temperature, freezing and thawing cycles have been evaluated. We believe that the optimized procedures during the sample handling secure reproducible spectra of good quality. In collection of serum samples, it is not uncommon to have hemolytic events due to rupturing of red blood cells during the processing steps. We noticed that, of the 58 subjects, 9 showed moderate hemolysis and were subjected to separate statistical evaluation. Hemolysis in the samples was evaluated by examination of the mass peaks at 7.6 and $15.1 \mathrm{kDa}$ corresponding to the double-charged and single-charged $\alpha$-subunit of hemoglobin, respectively. ${ }^{40}$ To avoid interference of the hemoglobin subunits in the proteomic profiling of the multiple serum specimens where the subunits may compete for or alter the binding affinity of other serum proteins to the surface ${ }^{40}$ samples with values $>80$ were excluded (see Table 3 and Figure 3). In the ASD group some children with severe autism were on medication with Risperdal to reduce hyperactivity and violent behavior, and a few children were on medication with Ritalin to improve attention (Table 1). It would have been ethically questionable to discontinue the medication with the purpose of controlling the research design. Although we did not see any detectable correlation between medication and the presence of the biomarker peptides in plasma samples of the ASD children it can not be excluded that some differences may be influenced by medications, as previously discussed. ${ }^{35}$ In a recently published study on complement factor I activity, ${ }^{42}$ we could

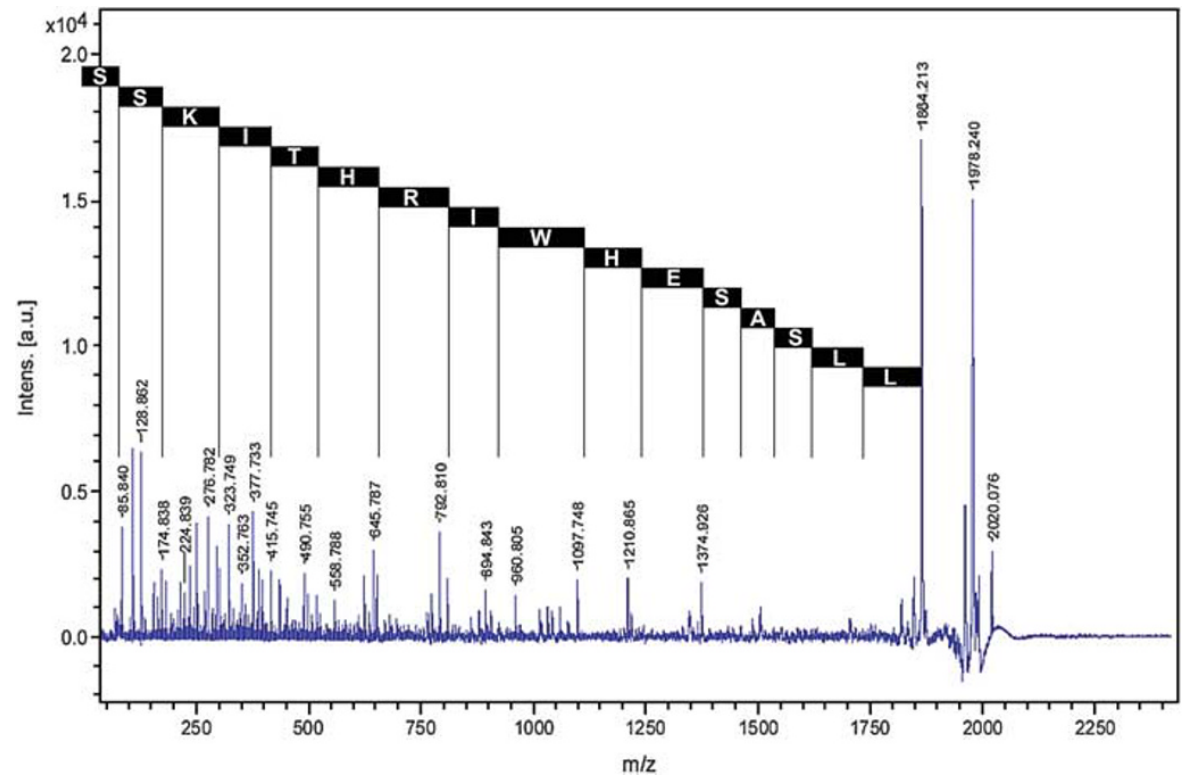

Figure 4 Typical MALDI TOF/TOF mass spectrum for sequence analysis. Fragmentation of C3f (2020.1 Da) to C3f-des-arginine (1864.2 Da) is identified with monoisotopic mass of arginine of $174.8\left(\mathrm{M}+\mathrm{H}^{+}\right)$, and to C3f-modified arginine (1978.1 Da). 
not find any clear influences of the medications also used by subjects in this study. Only six of the children in the ASD group had no medication. Of these five were correctly classified in the discrimination analysis and 1 was a sample with hemolysis and was incorrectly classified. Of the three biomarkers, $2020 \pm 1,1978 \pm 1$ and $1864 \pm 1$, identified in this proteomic profiling study of children with ASD and control children, the 1978-kDa ornithine-containing peptide identified by tandem MS is interesting as is suggest that the arginine of the 2020$\mathrm{kDa}$ peptide is recognized as a target for enzymatic conversion. As arginase requires a free arginine for conversion to ornithine $^{43}$ an interesting alternative possibility is that this C-terminal arginine residue is ADP-ribosylated by an argininespecific ADP-ribosyltransferase (ART) catalyzing the transfer of ADP-ribose from NAD ${ }^{+}$(ref. 44) with the possibility of a 'secondary' modification of the ADP-ribosylated arginine resulting in replacement of ADP-ribosylarginine by ornithine as shown for HNP-1. ${ }^{45}$ Lack of ART expression, that is ART2, has previously been correlated with enhanced susceptibility to autoimmune diseases (see Laing et al. ${ }^{44}$ and references therein). Altered immune function and complement-system deficiency has been reported for children with ASD indicating a recurrent incidence of immunological diseases. ${ }^{46-50}$ Other investigations has shown significantly increased levels of inflammatory markers such as TNF- $\alpha$, IL-6, IL-8, GM-CSF and IFN- $\gamma$ in the post mortem brain tissue of individuals with autism and immune dysfunction has also been proposed as a potential mechanism for the pathogenesis of ASD. ${ }^{21,51,52}$

By the proteomic approach used in this study we have identified differentially expressed peptides that correspond to fragments of the C3 complement protein. Although the study was based on a relatively limited group of children it demonstrates the potential of the proteomic approach in which the relevance and potential diagnostic utility of the panel of biomarkers was further strengthened by known associations between the protein or peptides and pathogenesis of ASD. By use of the proteomic approach we have discovered a unique set of biomarkers, which carries the potential for an early detection of ASD with an improved diagnostic accuracy that would enable an early intervention in the development of this disorder.

\section{Conflict of interest}

Naghi Momeni's PhD studentship was supported by Autism Biodiagnostics Sweden AB (ABSAB). ABSAB had no role in the design of the study, the collection or analysis of data. Dr Momeni has no financial holdings in that company, although he may receive some further compensation if his work leads to a commercial product. All the other authors declare no conflict of interest.

Acknowledgements. We thank Dr Maria Bergström at the Linnaeus University for her help with the experiments and the SELDI TOF MS analysis. Drs Jörg Hanrieder and Konstantin Artemenko at the Uppsala University are acknowledged for their assistance with high-resolution MS, and Dr Mohammad A Karbasian and staff at the Robat Karin Medical Diagnostic Laboratory, Tehran, for their assistance with collection of samples. We also thank all the children and their families who have contributed to this study. The principal funder of this project was Siamak Shahnooshi (Managing Director and company owner of Autism Biodiagnostics Ltd and Asbestos Consultants to the Environment Ltd-ACEPSI). Michael Krause was the financial director and Carl-Gunnar Nyquist was the Managing Director of the Swedish subsidiary company, Autism Biodiagnostics AB. The funder and his directors had no role in the study design, the data collection and analysis, or the preparation of the manuscript. The Swedish Research Council is acknowledged for grant 621-2008-3562 to JB.

1. Veenstra-Vanderweele J, Christian SL, Cook Jr EH. Autism as a paradigmatic complex genetic disorder. Annu Rev Genomics Hum Genet 2004; 5: 379-405.

2. Ozonoff $S$, Goodlin BL, Solomon M. A prospective study of the emergence of early behavioral signs of autism. J Am Acad Child Adolesc Psychiatry 2010; 49: 256-266.

3. American Psychiatric Association. Diagnostic and Statistical Manual of Mental Disorders (DSM-IV), 4th edn. American Psychiatric Association: Washington, DC, 2000.

4. London EA. The environment as an etiologic factor in autism: a new direction for research. Environ Health Perspec 2000; 108: 401-404.

5. Chakrabarti S, Fombonne E. Pervasive developmental disorders in preschool children: confirmation of high prevalence. Am J Psychiatry 2005; 162: 1133-1141.

6. Prevalence of Autism Spectrum Disorders-Autism and Developmental Disabilities Monitoring Network, Six Sites, United States, 2000. Centers for Disease Control and Prevention. MMWR Morb Mortal Wkly Rep 2007; 56 (SS01): 1-11.

7. Pinto D. Functional impact of global rare copy number variation in autism spectrum disorders. Nature 2010; 466: 368-372.

8. Kemper TL, Bauman MK. Neuropathology of infantile autism. Mol Psychiatry 2002; 7: 2-12.

9. Nelson KB, Grether JK, Croen LA, Dambrosia JM, Dickens BF et al. Neuropeptides and neurotrophins in neonatal blood of children with autism or mental retardation. Ann Neurol 2001; 49: 597-606.

10. Waterhouse L, Modahl C, Fein D. Neurofunctional mechanism in autism. Psycol Rev 1996; 103: 457-489.

11. Cook EH, Leventhal BL. The serotonin system in autism. Curr Op Pediat 1996; 8: 348-354.

12. Singh VK, Singh EA, Warren RP. Hyperserotoninemia and serotonin receptor antibodies in children with autism but not mental retardation. Biol Psychiatry 1997; 41: 753-755.

13. Tordjman S, Anderson GM, Mcbride PA, Hertzig ME, Snow ME, Hall LM et al. Plasma betaendorphin, adrenocorticotropin hormone, and cortisol in autism. J Child Psychol Psychiatry 1997; 38: 705-715.

14. Melke J, Goubran Botros H, Chaste P, Betancur C, Nygren G, Anckarsäter $\mathrm{H}$ et al. Abnormal melatonin synthesis in autism spectrum disorders. Mol Psychiatry 2008; 13: 90-98.

15. Scifo R, Cioni M, Nicolosi A, Batticane N, Tirolo C, Testa N et al. Opioid-immune interactions in autism: behavioural and immunological assessment during a double-blind treatment with nattrexone. Ann Ist Super Sanita 1996; 32: 351-359.

16. Pasca SP, Nemes B, Vlase L, Gagyi CE, Dronca E, Miu AC et al. High levels of homocysteine and low serum paraoxanase-1-arylesterase activity in children with autism. Life Sci 2006; 78: 2244-2248.

17. Krey JF, Dolmetsch RE. Molecular mechanisms of autism: a possible role for $\mathrm{Ca}^{2+}$ signaling. Curr Op Neurobiol 2007; 17: 112-119.

18. Glasson EJ, Bower C, Petterson B, de Klerk N, Chaney G, Hallmayer JF. Perinatal factors and the development of autism: a population study. Arch Gen Psychiatry 2004; 61: 618-627.

19. Momeni N, Nordström BM, Horstmann V, Averseji H, Sivberg BV. Alterations of prolyl endopeptidase activity in the plasma of children with autistic spectrum disorders. BMC Psychiatry 2005; 5: 1-6.

20. Modahl C, Green L, Fein D, Morris M, Waterhouse L, Feinstein C et al. Plasma oxytocin levels in autistic children. Biol Psychiatry 1998; 15: 270-277.

21. Li X, Chauhan A, Sheikh AM, Patil S, Chauhan V, Li XM et al. Elevated immune response in the brain of autistic patients. J Neuroimmunol 2009; 207: 111-116.

22. Delgiudice-Asch G, Holander E. Altered immune function in autism. CNS Spectr 1997; 2: 61-68.

23. Warren RP, Margaretten NC, Pace NC, Foster A. Immune abnormalities in patients with autism. J Autism Dev Disord 1986; 16: 189-197.

24. Warren RP, Yonk LJ, Burger RA, Cole P, Odell JD, Warren WL et al. Deficiency of suppressor-inducer (CD4+CD45RA+) T cells in autism. Immunol Invest 1990; 19: 245-251.

25. De Bruijn MH, Fey GH. Human complement component C3. cDNA coding sequence and derived primary structure. Proc Natl Acad Sci USA 1985; 82: 708-712.

26. Goldberger G, Bruns GA, Ris M, Edge MD, Kwiatkowski DJ. Human complement factor I: analysis of CDNA-derived primary structure and assignment of its gene to chromosome 4 . J Biol Chem 1987; 262: 10065-10071.

27. Soames CJ, Sim RB. Interactions between human complement components factor $\mathrm{H}$, factor I and C3b. Biochem J 1997; 1: 553-561.

28. Ganu VS, Muller-Eberhard HJ, Hugli TE. Factor C3f is a spasmogenic fragment released from $\mathrm{C} 3 \mathrm{~b}$ by factors $\mathrm{I}$ and $\mathrm{H}$ : the heptadeca-peptide $\mathrm{C} 3 f$ was synthesized and characterized. Mol Immunol 1989; 26: 939-948.

29. Janssen BJ, Huizinga EG, Raaimakers HC, Roos A, Daha MR, Nilsson-Ekdahl K et al. Structures of complement component $\mathrm{C} 3$ provide insights into the function and evolution of immunity. Nature 2005; 437: 505-511.

30. Petricoin EF, Ornstein DK, Liotta LA. Clinical proteomics: Applications for prostate cancer biomarker discovery and detection. Urol Oncol 2004; 22: 322-328. 
31. Huang JT, Leweke FM, Oxley D, Wang L, Harris N, Koethe D et al. Disease biomarkers in cerebrospinal fluid of patients with first-onset psychosis. PloS Med 2006; 3: 2145-2158.

32. Simonsen AH, McGuire J, Podust VN, Davies H, Minthon L, Skoog I et al. Identification of novel panel of cerebrospinal fluid biomarkers for Alzheimer's disease. Neurobiol Aging 2008; 29: 961-968.

33. Schwarz E, Guest PC, Rahmoune H, Wang L, Levin Y, Ingudomnukul E et al. Sex-specific serum biomarker patterns in adults with Asperger's syndrome. Mol Psychiatry 2011; 16: 1213-1220.

34. Junaid MA, Kowal D, Barua M, Pullarkat PS, Sklower Brooks S, Pullarkat RK. Proteomic studies identified a single nucleotide polymorphism in glyoxalase I as autism susceptibility factor. Am J Med Genet A 2004; 131: 11-17.

35. Corbett BA, Kantor AB, Schulman H, Walker WL, Lit L, Ashwood P et al. A proteomic study of serum from children with autism showing differential expression of apolipoproteins and complement proteins. Mol Psychiatry 2007; 12: 292-306.

36. Lord C, Rutter M, Dilavore P, Risi S. Autism Diagnostic Observation Schedule (ADOS). Western Psychological Services: Los Angeles, CA, 1999

37. Rutter M, LeCouteur AL, Lord C. Autism Diagnostic Interview - Revised. Western Psychological Services: Los Angeles, CA, 2003.

38. Johnson CP, Myers SM, the Council on Children with Disabilities. Embargo Policy Identification and evaluation of children with autism spectrum disorders. Am Acad Pediatr 2007; 120: 1183-1215

39. Morrison DF. Multivariate Statistical Methods, 3rd edn. McGraw-Hill: New York, NY, 1990

40. Drake RR, Cazares LH, Corsica A, Malik A, Schwegler EE et al. Quality control, preparation and protein stability issues for blood serum and plasma used in biomarker discovery and proteomic profiling assays. BioProcess J 2004; 3: 45-50.

41. Hanley JA, Mc Neil BJ. The meaning and use of the area under a receiver operating characteristic (ROC) curve. Radiology 1982; 143: 29-36.

42. Momeni N, Brudin L, Behnia F, Nordström B, Yosefi-Oudarii A, Sivberg B et al. High complement factor I activity in the plasma of children with autism spectrum disorders. Autism Res Treatment 2012; doi: 10.1155/2012/868576.
43. Jenkinson $\mathrm{CP}$, Grody WW, Cederbaum SD. Comparative properties of arginases. Comp Biochem Physiol B Biochem Mol Biol 1996; 114: 107-132.

44. Laing S, Unger M, Koch-Nolte F, Haag F. ADP-ribosylation of arginine. Amino Acids 2011; 41: 257-269.

45. Stevens LA, Levine RL, Gochuico BR, Moss J. ADP-ribosylation of human defensin HNP-1 results in the replacement of the modified arginine with the noncoded amino acid ornithine. Proc Natl Acad Sci USA 2009; 106: 19796-19800.

46. Morgan BP, Walport MJ. Complement deficiency and disease. Immunol Today 1991; 12 : 301-316

47. Warren RP, Foster A, Margaretten NC. Reduced natural killer cell activity in autism. J Am Acad Child Adolesc Psychiatry 1987; 26: 333-335.

48. Careaga M, Van de Water J, Ashwood P. Immune dysfunction in autism: a pathway to treatment. Neurotherapeutics 2010; 7: 283-292.

49. Zimmerman AW. Commentary: Immunological treatments for autism: in search reasons for promising approaches. J Autism Dev Disord 2000; 30: 481-484.

50. Pardo CA, Vargas DL, Zimmerman AW. Immunity, neuroglia and neuroinflammation in autism. Int Rev Psychiatry 2005; 17: 485-495.

51. Gupta S, Aggarwal S, Heads C. Dysregulated immune system in children with autism: beneficial effects of intravenous immune globulin on autistic characteristics. J Autism Dev Disord 1996; 26: 439-452.

52. Ashwood P, Corbett BA, Kantor A, Schulman H, Van de Water J, Amaral DG. In search of cellular immunophenotypes in the blood of children with autism. PLOS One 2011; 6: 1-9.

(c) Translational Psychiatry is an open-access journal published by Nature Publishing Group. This work is licensed under the Creative Commons Attribution-Noncommercial-No Derivative Works 3.0 Unported License. To view a copy of this license, visit http://creativecommons.org/licenses/by-nc-nd/3.0/ 